\title{
CHANGE MANAGEMENT IN MALAYSIA INFRASTRUCTURE PROJECT: ROLE OF SUBCONTRACTORS
}

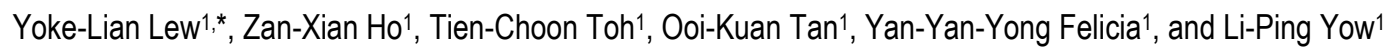

${ }^{1}$ LKC Faculty of Engineering \& Science, University Tunku Abdul Rahman, Sungai Long, Malaysia

\begin{abstract}
Implementation of change management is necessary for any construction projects especially infrastructure projects where government allocated billions of ringgit for the country development and the impact of change can be minimised if attended earlier. Nowadays, subcontractors were hired by the contractor to carry out the actual work as subcontracting is a very common practice in this industry. This research was initiated to identify the possible causes of change and then investigated the current status of change management implementation in Malaysia's infrastructure project. A questionnaire survey was designed to collect data for this research. 102 out of 130 sets of questionnaires were collected from the targeted respondents. Then, a comprehensive analysis was conducted. It was discovered that "design change", "addition/omission of scopes" and "ambiguities and mistakes in specifications and drawings" were ranked as top three factors contributing to change in Malaysia' infrastructure projects. This research also discovered that the implementation status of change management was surprisingly high with $72.54 \%$ of the infrastructure projects implemented change management. Lastly, the subcontractors' involvement in contractor's change management process affected the project performance positively was confirmed in this research as the projects with subcontractor involvement had statistically significant better project performance in terms of time, cost and quality of work. The identification of the root cause for change in infrastructure project helps the future project practitioners to avoid such situation and more well-prepared for it. Subsequently, this research discovered the benefit of practising change management within the infrastructure projects and getting the subcontractor involvement statistically. The findings of this research could improve the project performance of Malaysia's infrastructure projects.
\end{abstract}

ARTICLE HISTORY

Received: 8-10-2020

Accepted: 3-12-2020

\section{KEYWORDS}

Change,

Change Management,

Subcontractor,

Project Performance

\section{INTRODUCTION}

The target for any industry is to complete the project within the agreed period of time and allocated budget. However, a delay is a universal phenomenon in construction projects and change order is one of the universal delay factors (Zidane $\&$ Andersen, 2018). Change is one of the usual concerns and very likely to happen in construction projects. Changes could arise at any phase of a project and due to numerous causes from different sources (Motawa et al., 2007). The change that occurred would affect the project negatively, for example, schedule delays, cost overruns and affecting the quality if it is not managed in a proper manner through a formalised change management process (Anees, Mohamed \& Razek, 2013). The earlier the changes are attended, the lesser the impact of the change on the project performance. In short, the implementation of change management is necessary for construction projects.

The implementation of change management is necessary for any construction projects especially infrastructure projects where the government allocated billions of ringgit for the country's development and the impact of change can be minimised if attended earlier. Malaysian government spent RM 16.5 billion on the construction work done in the 1st quarter of 2019 just for this purpose. The 11th Malaysia Plan (Rancangan Malaysia ke-11, 2016-2020) introduced by the then-Prime Minister of Malaysia on 21st May 2015 emphasised the development of public transport, in particular for the connectivity from countrysides to the cities (PNMB, 2015). As mentioned in the plan, the expansion and integration of the existing network will create new paths of economic activity. As a result, there are many infrastructure projects introduced, for example, Pan-Borneo Highway, KVMRT SBK Line, KVMRT SSP Line, High-Speed Rail, WCE, East Coast Rail Link, LRT Line 3, and many more. Most of the abovementioned projects have already started and now are at different stages of development. According to the statistics prepared by CIDB Malaysia, there are 14,162 infrastructure projects awarded from the year 2010 to the first half of 2017 as of June 2017 with a total project value of RM 360 billion (CIDB, 2017). The delivery capability of the main contractor in construction projects is highly determined by their subcontractors due to sixty to seventy percent of the work is subcontracted to subcontractors (Loh \& Ofori, 2013). This is no exception in Malaysia, where usually in huge projects, the main contractor will subcontract their works out to multiple subcontractors (Lew et al., 2018). Thus, this research is initiated to look into the current change management implementation status in Malaysia's infrastructure project and analyse the effect of the involvement of subcontractors in change management toward the project performance. 


\section{LITERATURE REVIEW}

\section{Infrastructure Projects in Malaysia}

In Malaysia, construction is one of the crucial sectors that contribute to economic growth as the construction sector contributed close to $4.2 \%$ of GDP in the year 2018. Other than that, this sector already forked up RM 194 billion to GDP which at $11.1 \%$ growth per annum during the year 2011 to 2015 as stated in the 11th Malaysia Plan (PNMB, 2015). In Malaysia, the public and private sectors are the two main sectors for construction. The government as the largest consumer in Malaysia as the public sector propelled the construction activity with $44.0 \%$ of the share in the First Quarter of 2019 (PNMB, 2015). The government allocated billions of ringgit on the development of Malaysia's infrastructure, to strengthen the foundation to support economic growth. The economy and social development would be severely hindered without proper infrastructure in place.

\section{Involvement of Subcontractors in Malaysia Construction Industry}

Subcontractors are defined as the contractors who are hired by the main contractor specifically to carry certain tasks on a project and it is usual that 20 to 30 subcontractors are employed on a single project (Hinze \& Tracey, 1994). This is because nowadays, the main contractor only acts as a construction management agency where they just control and coordinate the works of subcontractors. The achievement of the project performance at the end of the construction project relies on the subcontractors' performance. However, even though the actual works are performed by the subcontractor, the main contractor is still accountable to deliver the work to the owner (Polat, Kaplan \& Bingol, 2015).

The delivery capability of the main contractor in construction projects is highly determined by their subcontractors due to sixty to seventy percent of the work is subcontracted to subcontractors (Loh \& Ofori, 2013). Subcontractors facilitate the work by providing quotations for the subcontracted work. The subcontractors will bear the extra costs and resources of delays for acceleration if the progress is not in good shape (Loh \& Ofori, 2013). The completion of the project on time relies on the capability of the subcontractor. The underperformance of the subcontractor will hinder the progress of the project. The root cause for inefficiencies in Malaysia construction industry is due high percentage of subcontracting where directly increased the risk of delays (Sambasivan \& Soon, 2007).

\section{Change Management}

A quantitative research conducted by Ramanathan and Narayanan (2014) investigated the factors that caused time delay and cost overrun in Malaysia design and build construction projects. Change orders from owners in the construction stage ranked as one of the top ten factors in this research. The major factor that causes construction delays in Klang Valley was identified in the quantitative research by Hasmori et al. (2018) and changes of order was ranked as the 6th factor that contributes to delays. From the perspective of a contractor, too many change orders are viewed as the secondhighest delay factor in Jordan's construction project in a quantitative research conducted by Sweis et al. (2008).

Any changes or alterations to the project objectives and scope are classified as change regardless of the impact to the project performance (Hwang \& Low, 2012). In short, any alteration to the contractual agreement between contractors or owners is change. The impact of change can be significant as it hinders the progress and operation of the project. The rework in construction is always accompanied by the demolition of works done and critical change will have a bigger effect such as consecutive delays in project schedule, re-estimation of the work programme, and additional resources to catch up the progress (Anees, Mohamed \& Razek, 2013).

The impact of change on project performance is undesirable as it will lead to scope creep if the change is uncontrolled and short of reviews to schedule and budget (PMI, 2017; Yap, Abdul-Rahman \& Chen, 2017). Wu, Hsieh, and Cheng (2005) stated that the main cause of delay and cost overrun in most public works are due to design changes. Furthermore, the researchers also mentioned that design changes lead to multiple negative impacts, for example, low morale, legal disputes, and quality discrepancies.

\section{METHODOLOGY}

A questionnaire survey that enables a large research sample size to be collected in a limited time frame was adopted for this research. The questionnaire for this research was developed based on close-ended questions. The respondents were requested to answer all of the questions from a defined list of choices and rating scale to enable the respondents to indicate the degree of agreement or disagreement with a particular statement. Section I of the questionnaire collected the demographic data of the respondents. Then, respondents were asked to rate the possible causes leading to changes in construction projects based on a 5-point Likert scale in Section II. In Section III, the implementation status of the change management was collected. Lastly, the respondents were required to indicate the achievement of the project performance for the project in the final section.

According to Roscoe (1975), the rule of thumb for appropriate sample size for a research is ranging from 30 to 500 . Then Gorsuch (1983) and Kline (1994) recommended that an appropriate sampling size is at least 100 subjects. The research done by MacCallum et al. (1999) also suggested a sample size of 100 was adequate. Thus, in this research, a sample size of a minimum of 100 valid responses was proposed. The personnel who worked or are working in Malaysia's infrastructure project such as owner, contractor, consultant, and subcontractor were the targeted population for this research. A random sampling method was adopted in selecting the respondents to receive the questionnaire. A pre-test on the questionnaire was conducted with three experts from infrastructure projects to discover if there is any problem 
with the developed questionnaire. A pre-test is important to ensure the developed questionnaire is designed and developed adequately to suit the purpose of the research (De Leeuw, Borgers \& Smits, 2004). A number of refinements including merging of some causes listed and revision on sentences were done according to the outcome of the pre-test.

\section{FINDINGS AND DISCUSSION}

100 out of 130 sets of questionnaires were sent to targeted respondents through emails and Google form. A total number of 102 sets of responded questionnaires were received at the end of data collection activity with a response rate of $78 \%$. The respondents' background and the project data are summarised in Table 1 below. The results were analysed using SPSS.

Table 1: Respondent Background

\begin{tabular}{|c|c|c|c|}
\hline & Construct & Frequency & Percentage (\%) \\
\hline \multirow[t]{5}{*}{ (1) } & Role in Infrastructure Project & & \\
\hline & Owner/Client & 2 & 2.0 \\
\hline & Consultant & 2 & 2.0 \\
\hline & Contractor & 73 & 71.6 \\
\hline & Subcontractor & 25 & 24.5 \\
\hline \multirow[t]{8}{*}{ (2) } & Current position in company & & \\
\hline & Engineer & 30 & 29.4 \\
\hline & Senior Engineer & 23 & 22.5 \\
\hline & Lead Engineer & 11 & 10.8 \\
\hline & Assistant Manager & 8 & 7.8 \\
\hline & Manager & 22 & 21.6 \\
\hline & Project Manager & 2 & 2.0 \\
\hline & Others & 6 & 5.9 \\
\hline \multirow[t]{5}{*}{ (3) } & Experience in construction industry & & \\
\hline & $<5$ years & 41 & 40.2 \\
\hline & $\geq 5$ to 10 years & 45 & 44.1 \\
\hline & $\geq 10$ to 20 years & 15 & 14.7 \\
\hline & $>20$ years & 1 & 1.0 \\
\hline \multirow[t]{7}{*}{ (4) } & Project Sector in the Infrastructure Project & & \\
\hline & Road & 17 & 16.7 \\
\hline & Railway & 71 & 69.6 \\
\hline & Energy & 3 & 2.9 \\
\hline & Building & 8 & 7.8 \\
\hline & Oil and Gas & 2 & 2.0 \\
\hline & Other & 1 & 1.0 \\
\hline \multirow[t]{5}{*}{ (5) } & Role in the Infrastructure Project & & \\
\hline & Owner/Client & 2 & 2.0 \\
\hline & Consultant & 2 & 2.0 \\
\hline & Contractor & 73 & 71.6 \\
\hline & Subcontractor & 25 & 24.5 \\
\hline \multirow[t]{10}{*}{ (6) } & Contract Size of the Infrastructure Project & & \\
\hline & $>$ RM 0.5 million to 1 million & 6 & 5.9 \\
\hline & >RM 1 million to 5 million & 12 & 11.8 \\
\hline & >RM 5 million to 10 million & 7 & 6.9 \\
\hline & >RM 10 million to 50 million & 27 & 26.5 \\
\hline & >RM 50 million to 100 million & 16 & 15.7 \\
\hline & >RM 100 million to 300 million & 15 & 14.7 \\
\hline & $>$ RM 300 million to 500 million & 1 & 1.0 \\
\hline & >RM 500 million to 1 billion & 8 & 7.8 \\
\hline & $>$ RM 1 billion & 10 & 9.8 \\
\hline
\end{tabular}

\section{Causes leading to change in infrastructure project}

The respondents were requested to rate the 36 causes according to the degree of agreement on their contribution to the changes in infrastructure projects from scale 1 (Strongly Disagree) to 5 (Strongly Agree). After that, the relative importance index for each cause was calculated. 
Table 2: RII and Rank for Causes Leading to Change in Infrastructure Projects

\begin{tabular}{|c|c|c|}
\hline Causing factors of changes & RII & Rank \\
\hline Design Change & 0.841 & 1 \\
\hline Addition/omission of scopes & 0.835 & 2 \\
\hline Ambiguities and mistakes in specifications and drawings & 0.816 & 3 \\
\hline Owner's need during design stage are unclear or not well-defined & 0.808 & 4 \\
\hline Discrepancy between as-builts and as-design & 0.806 & 5 \\
\hline Incomplete/inconsistent drawings & 0.796 & 6 \\
\hline Change of requirement/specification & 0.794 & 7 \\
\hline Slow decision-making & 0.792 & 8 \\
\hline Improper technical study by the contractor during the bidding stage & 0.792 & 8 \\
\hline Failure by the consultant to perform design and supervision effectively & 0.790 & 10 \\
\hline Uncertainties of project & 0.782 & 11 \\
\hline Poor overall project planning & 0.780 & 12 \\
\hline Poor project management by contractor & 0.776 & 13 \\
\hline Poor communication between relevant governmental units and the owner & 0.773 & 14 \\
\hline Value Engineering & 0.769 & 15 \\
\hline Insufficient of competent staff in the contractor's organization & 0.769 & 15 \\
\hline To meet owner expectations & 0.769 & 15 \\
\hline Poor communication among stakeholders & 0.765 & 18 \\
\hline Conflict between contract documents & 0.759 & 19 \\
\hline The scope of work for the contractor is not well defined & 0.753 & 20 \\
\hline Shortage of Resources & 0.753 & 20 \\
\hline Insufficient coordination among stakeholders & 0.749 & 22 \\
\hline Constructability ignored in the design process & 0.741 & 23 \\
\hline Inaccurate cost estimating & 0.741 & 23 \\
\hline Change of financial status of any party involved in the project & 0.737 & 25 \\
\hline Changes in government regulations, laws, and standards & 0.735 & 26 \\
\hline Economic condition & 0.735 & 26 \\
\hline Incompetent Consultant assigned to the project & 0.733 & 28 \\
\hline Modifications to the drawings leading to infective design & 0.731 & 29 \\
\hline Unanticipated site conditions & 0.724 & 30 \\
\hline Change in management of any party involved in the project & 0.720 & 31 \\
\hline Failure by the consultant to perform design and supervision effectively & 0.718 & 32 \\
\hline Change in design by the consultant & 0.714 & 33 \\
\hline Quality defect & 0.696 & 34 \\
\hline Change in material & 0.690 & 35 \\
\hline Inclement weather & 0.629 & 36 \\
\hline
\end{tabular}

Table 2 presented the RII's weightage and the ranking of each cause based on responses received from the respondents. The 36 causes were arranged and ranked accordingly by referring to their RII's weightage. The higher the RII's weightage, the higher the cause is ranked. The RII's weightage of the causes with the responses from all the respondents are in the range of 0.629 to 0.841 .

In the respondents' view, design change is the primary causes of change in infrastructure project with an overall RII of 0.841 and it is the number 2 cause which lead to change in railway project as well. Past studies have also shown that design change is the primary factor of rework in construction projects worldwide (Yap, Abdul-Rahman \& Chen, 2017). This is no exception in Malaysia's infrastructure project as it was ranked number 1 by all the respondents. The "addition/omission of scopes" received the second rank by all the respondents. This cause obtained rank number 2 with the overall RII of 0.835. "Ambiguities and mistakes in specifications and drawings" received rank number 3 by all the respondents with the RII of 0.816 . The number 4 and number 5 causes are "owner's need during design stage are unclear or not well-defined" and "discrepancy between as-builts and as-design" with an overall RII of 0.808 and 0.806 respectively. 
The result revealed the primary causes of change are owner/client-related as three out of the first five causes are owner/client-related when the design change also could be initiated by the owner/client. The result is tally to the research done by Alnuaimi et al. (2009) as the researcher also agreed that owner/client is the main cause of change infrastructure projects. The design change normally is driven by the infrastructure projects' owner due to the desire to have additional features (Yap, Abdul-Rahman \& Chen, 2017). The added features are considered as additional requirements to the contractor and directly increased the scope of work. This is the reason behind why the "design change" and "addition/omission of scopes" are the top two causes leading to change in infrastructure projects.

The plausible explanations for "ambiguities and mistakes in specifications and drawings" and "owner's need during design stage are unclear or not well-defined" are ranked 3rd and 4th respectively is due to the owner was not participating in the design development (Alnuaimi et al., 2009). The designer developed the design based on their own understanding of the specifications and drawings with no involvement from the owner in the design development. Changes are resulted due to the different understanding of the specification from both parties or owner's need are unclear or not well-defined for the designer to design accordingly. This is because the owner had difficulty to visualise the end product they requested (Anees, Mohamed \& Razek, 2013). The unforeseen site issues during the construction period cause the as-built deferred from the as-designed as the modification is necessary on the design to suit the site condition (Mpofu et al., 2017).

Change management implementation status

Table 3: Change Management Implementation Status

\begin{tabular}{|c|c|c|c|c|}
\hline \multicolumn{2}{|c|}{ Project Characteristic } & \multirow{2}{*}{$\begin{array}{l}\text { Number of } \\
\text { Projects } \\
17\end{array}$} & \multirow{2}{*}{$\begin{array}{l}\text { Number of Projects } \\
\text { Implementing Change } \\
\text { Management }\end{array}$} & \multirow{2}{*}{$\begin{array}{l}\text { Percentage of } \\
\text { Projects } \\
\text { Implementing } \\
\text { Change } \\
\text { Management } \\
23.5 \%\end{array}$} \\
\hline Project & Road & & & \\
\hline \multirow[t]{5}{*}{ Sector } & Railway & 71 & 62 & $87.32 \%$ \\
\hline & Energy & 3 & 0 & $0 \%$ \\
\hline & Building & 8 & 5 & $62.5 \%$ \\
\hline & Oil and Gas & 2 & 2 & $100 \%$ \\
\hline & Other (Telecommunication) & 1 & 1 & $100 \%$ \\
\hline Project & $>\mathrm{RM} 0.5$ million to 1 million & 6 & 5 & $83.33 \%$ \\
\hline \multirow[t]{8}{*}{ Cost } & $>$ RM 1 million to 5 million & 12 & 5 & $41.67 \%$ \\
\hline & $>$ RM 5 million to 10 million & 7 & 5 & $71.43 \%$ \\
\hline & $>$ RM 10 million to 50 million & 27 & 25 & $92.59 \%$ \\
\hline & > RM 50 million to 100 million & 16 & 14 & $87.5 \%$ \\
\hline & $>$ RM 100 million to 300 million & 15 & 5 & $33.33 \%$ \\
\hline & >RM 300 million to 500 million & 1 & 0 & $0 \%$ \\
\hline & $>$ RM 500 million to 1 billion & 8 & 7 & $87.5 \%$ \\
\hline & $>$ RM 1 billion & 10 & 8 & $80 \%$ \\
\hline Total & & 102 & 74 & $72.54 \%$ \\
\hline
\end{tabular}

In general, out of 102 infrastructure projects, 74 projects practiced change management with a percentage of $72.54 \%$. The result indicating the current status of change management implementation in Malaysia's infrastructure projects is moderately high. The result obtained is surprisingly different from the research carried out by Hwang and Low (2012) as the low percentage of Singapore's construction projects practiced change management.

As shown in Table 3, in general, the change management implementation is moderately high as very high percentage $(>80 \%)$ of Oil and Gas, Telecommunication, and Railway projects implemented change management. These mega infrastructure projects are large in scale with high complexity in terms of structural, technical, and organisational complexity (Chapman, 2016). Many mega infrastructure projects suffered from budget overrun and time delays due to the complexity of the projects. Therefore, change management process is a must for these projects to ensure the changes are addressed in a timely manner (Hwang \& Low, 2012). If the changes are attended to promptly, the effect of change on the overall project performance can be minimised.

Last but not least, in Table 3, all the projects were categorised based on their contract size. $87.5 \%$ and $80 \%$ of the projects cost more than RM 500 million to RM 1 billion and RM 1 billion above practiced change management. The percentage of change management implementation likely to be higher for the projects involved a large amount of project cost. This is supported by the research by Hwang and Low (2012), as project cost is the main factor that motivates companies to practice change management within their project. Majority of the projects cost more than RM 10 million to 50 million and more than RM 50 million to 100 million, the percentage of the implementation is relatively high as most of the projects are railway projects. As mentioned earlier, change management is necessary for the high complexity project and this is the rationale behind the high percentage of change management implementation. 


\section{Effect of change management towards project performance}

Table 4 below shows the effect of change management toward the project performance with regards to time, cost, and quality. Table 5 indicated the project with change management performed better in time efficiency as having a higher mean rank. Mann-Whitney U test was tested with a 95\% confidence interval (CI) for the mean difference. It was revealed that the projects with change management implemented had statistically significant higher time efficiency compared to the projects without the implementation of change management $(U=472.000, p=0.000)$. Hence, it can be concluded that the implementation of change management affected the time performance of the project positively. For cost efficiency, the projects with the change management implemented likely to perform slightly greater than the other group with a mean rank of 58.64 compared to 32.63. Mann-Whitney U test was tested with a 95\% CI for the mean difference. It was discovered that the projects that practiced change management had statistically significant higher cost-efficiency compared to the projects without the implementation of change management, $(U=507.500, p=0.000)$. Hence, it can be concluded that the implementation of change management affected the project's cost performance positively. As seen in Table $4,72.54 \%$ of the projects that implemented change management have a mean rank of 56.53 on the work quality achieved while the projects without change management have a mean rank of 38.21. The achievement of the quality of work of the projects is slightly better than the projects without change management. Mann-Whitney U test was tested with a 95\% CI for the mean difference. No surprise, it was found that the projects with change management implemented had a statistically significant better quality of work compared to the projects without the implementation of change management $(U=664.000, p=0.003)$. Thus, in a nutshell, the change management improved the work quality for the project even though the difference of the mean score between the two groups is not as high as time and cost-efficiency. This finding is supported by research from Hwang and Low (2012). Furthermore, they mentioned the improvement of quality by change management is lower than time and cost because the improvement of quality is unable to measure as explicit as time and cost.

Overall, the project performance for the projects with change management implemented was performed slightly better than the project without change management. These results are expected and matched with the previous research carried out by Hwang and Low (2012) where they suggested the practiced change management improved the project performance slightly as the project changes identified and resolved at the earlier phase will have a lesser effect on the project performance.

Table 4: Effect of Change Management toward Project Performance

\begin{tabular}{|c|c|c|c|c|c|c|c|c|}
\hline & \multicolumn{3}{|c|}{ With Change Management } & \multicolumn{3}{|c|}{ Without Change Management } & \multirow{2}{*}{$\begin{array}{l}\text { Mann- } \\
\text { Whitney } \\
\text { U }\end{array}$} & \multirow[b]{2}{*}{$P$ value } \\
\hline & Number & $\begin{array}{l}\text { Mean } \\
\text { Rank }\end{array}$ & $\begin{array}{l}\text { Sum of } \\
\text { Ranks }\end{array}$ & Number & $\begin{array}{l}\text { Mean } \\
\text { Rank }\end{array}$ & $\begin{array}{l}\text { Sum of } \\
\text { Ranks }\end{array}$ & & \\
\hline $\begin{array}{l}\text { Time } \\
\text { Efficiency }\end{array}$ & 74 & 59.12 & 4375.00 & 28 & 31.36 & 878.00 & 472.000 & 0.000 \\
\hline $\begin{array}{l}\text { Cost } \\
\text { Efficiency }\end{array}$ & 74 & 58.64 & 4339.50 & 28 & 32.63 & 913.50 & 507.500 & 0.000 \\
\hline $\begin{array}{l}\text { Quality of } \\
\text { Work }\end{array}$ & 74 & 56.53 & 4183.00 & 28 & 38.21 & 1070.00 & 664.000 & 0.003 \\
\hline
\end{tabular}

\section{Effect of subcontractor involvement in change management}

The involvement of subcontractor in contractor's change management process was analysed with the input received from the respondents. In general, 42 out of 74 projects involved subcontractors in their own change management process with a percentage of $56.76 \%$. There are slightly more than half of the contractors obtaining subcontractor input by involving them in the change management process. There is no comparison on the result of previous research due to not having similar research in this area for the moment. Based on Table 6, the projects with the subcontractor involved in the change management process tend to have a slightly better achievement on the time efficiency with a mean rank of 46.19 compared to 26.09 for the projects without subcontractor involvement. Mann-Whitney U test was tested with a 95\% CI for the mean difference. It was revealed that the projects with subcontractor involvement had statistically significant higher time efficiency compared to the projects without subcontractor involvement, $(\mathrm{U}=307.000, p=0.000)$. Hence, it can be concluded that subcontractor involvement in contractor's change management process affected the time performance of the project positively.

As presented in Table 5 below, the projects with the subcontractor involved in the change management process achieved better cost efficiency with a mean rank of 45.24 compared to 27.34 for the projects without subcontractor involvement. Mann-Whitney U test was tested with a 95\% CI for the mean difference. It was revealed that the projects with subcontractor involvement had statistically significant higher cost-efficiency compared to the projects without subcontractor involvement, $(\mathrm{U}=347.000, p=0.000)$. Hence, it can be concluded that subcontractor involvement in contractor's change management process affected the cost performance of the project positively. For the work quality, the projects with the subcontractor involved in the change management process have better achievement with a mean rank of 45.36 compared to 27.19 for the projects without subcontractor involvement as shown in Table 6. Mann-Whitney $\mathrm{U}$ test was tested with a $95 \% \mathrm{CI}$ for the mean difference. It revealed that the projects with subcontractor involvement had statistically significant better work quality compared to the projects without subcontractor involvement, $(\mathrm{U}=342.000$, 
$p=0.000)$. Hence, it can be concluded that subcontractor involvement in contractor's change management process improved the project work quality.

Overall, the project performance for the projects with the involvement of subcontractor was better than the project without involvement from subcontractor. However, the impact is only very slight as the mean score between the two groups is very little in general. The reason why the involvement of subcontractors affected the project performance is that the main contractor only acts as the management agencies where they just control and coordinate the works of subcontractors (Polat, Kaplan \& Bingol, 2015). Hence, the involvement of the subcontractor plays an importance role as they are the one to carrying out the work. With the input from the subcontractor, changes can be identified and resolved earlier leading to lesser impact on the project performance.

Table 5: Mann- Whitney U Test: Mean Rank on Effect of Subcontractor involvement toward Project Performance

\begin{tabular}{llllllllll}
\hline & \multicolumn{2}{l}{ With Subcon Involvement } & \multicolumn{2}{c}{ Without Subcon Involvement } & Mann- & P value \\
\cline { 2 - 7 } & Number & $\begin{array}{l}\text { Mean } \\
\text { Rank }\end{array}$ & $\begin{array}{l}\text { Sum } \\
\text { Ranks }\end{array}$ & of & Number & $\begin{array}{l}\text { Mean } \\
\text { Rank }\end{array}$ & $\begin{array}{l}\text { Sum of } \\
\text { Ranks }\end{array}$ & Whitney U & \\
\hline $\begin{array}{l}\text { Time } \\
\text { Efficiency }\end{array}$ & 42 & 46.19 & 1940.00 & 32 & 26.09 & 835.00 & 307.000 & 0.000 \\
$\begin{array}{l}\text { Cost } \\
\begin{array}{l}\text { Efficiency } \\
\text { Quality of } \\
\text { Work }\end{array}\end{array}$ & 42 & 45.24 & 1900.00 & 32 & 27.34 & 875.00 & 347.000 & 0.000 \\
\hline
\end{tabular}

\section{CONCLUSION}

In conclusion, all three research objectives set for this research were addressed and achieved. The first objective was addressed as the top five causes contribute to change in Malaysia's infrastructure project were identified. The current change management implementation status in Malaysia's infrastructure projects was investigated and the overview is presented in the research report in order to achieve the second research objective. Last but not least, the effect of subcontractor involvement in change management toward project performance was analysed to achieve the last research objective. Recognising the factors contributing to change, the implementation of status, and also the impacts of change management would benefit the industry as changes that affect project performance negatively could be eliminated or reduced and subsequently improve the project performance of Malaysia's infrastructure projects.

Due to time constraints, data are mostly based on the infrastructure projects in Klang Valley. It is unable to cover the infrastructure projects in other states of Malaysia. Therefore, the findings presented in the discussion might not accurately represent the entire population of the infrastructure projects in Malaysia.

\section{REFERENCES}

Alnuaimi, A. S., Taha, R A., Mohsin, M. A. \& Al-Harthi, A. S. (2009). Causes, Effects, Benefits, and Remedies of Change Orders on Public Construction Projects in Oman. Journal of Construction Engineering and Management, 136(5), pp. 615-622.

Anees, M. M., Mohamed, H. E. \& Abdel Razek, M. E. (2013). Evaluation of change management efficiency of construction contractors. HBRC Journal, 9(1), pp. 77-85.

CIDB. (2017). Main Statistic On Construction Projects Awarded. [online] Available at:<http://www.cidb.gov.my/images/content/pdf/statistik/Construction-Industry-Statistic---Jun-2017.pdf> [Accessed 06 November 2019].

Chapman, R. J. (2016). A framework for examining the dimensions and characteristics of complexity inherent within rail megaprojects. International Journal of Project Management, 34(6), pp. 937-956.

De Leeuw, E., Borgers, N. and Smits, A. (2004). Pretesting Questionnaires for Children and Adolescents. Methods for Testing and Evaluating Survey Questionnaires, pp. 409-429.

Gorsuch, R. L. (1983). Factor Analysis. 2nd ed. Hillsdale, NJ: Erlbaum.

Hasmori, M. F., Said, I., Deraman, R., Abas, N.H.,Nagapan, S., Ismail, M.H.,Khalid, F.S. \& Roslan, A.F. (2018). Significant Factors of Construction Delays Among Contractors in Klang Valley and its Mitigation. International Journal of Integrated Engineering, 10(2), pp. 32-36.

Hinze, J. \& Tracey, A. (1994). The Contractor-Subcontractor Relationship: The Subcontractor's View. Journal of Construction Engineering and Management, 120(2), pp. 274-287.

Hwang, B. G. \& Low, L. K. (2012). Construction project change management in Singapore: Status, importance and impact. International Journal of Project Management, 30(7), pp. 817-826.

Kline, P. (1994). An Easy Guide To Factor Analysis. 1st ed. New York: Routledge.

Lew, Y. L., Hassim, S.,Muniady, R. \& Law, T.H. (2018). Structural equation modelling for subcontracting practice: Malaysia chapter. Engineering, Construction and Architectural Management, 25(7), pp. 835-860.

Loh, W. H. \& Ofori, G. (2013). Effect of registration on performance of construction subcontractors in Singapore. Engineering, Construction and Architectural Management, 7(1), pp.29-40.

MacCallum, R. C., Widaman, K.F., Zhang, S. and Hong, S. (1999). Sample size in factor analysis. Psychological Methods, 4(1), pp. 84-99

Mpofu, B., Godfrey, E., Moobela, O.C. \& Pretorious, A. (2017). Profiling causative factors leading to construction delays in the United 
Arab Emirates. Engineering, Construction and Architectural Management, 24, pp. $511-532$.

Motawa, I. A., Anumba, C.J., Lee, S. \& Peña-Mora, F. (2007). An integrated system for change management in construction. Automation in Construction. 16(2007), pp. 2006-2008.

PNMB. (2015). Eleventh Malaysia Plan 2016-2020 Anchoring Growth on People. [online] Available at:< https://www.talentcorp.com.my/clients/TalentCorp_2016_7A6571AE-D9D0-4175-B35D99EC514F2D24/contentms/img/publication/RMKe-11\%20Book.pdf> [Accessed 06 November 2019]

Polat, G., Kaplan, B. \& Bingol, B. N. (2015). Subcontractor Selection using Genetic Algorithm. Procedia Engineering, 123, pp. 432440.

Project Management Institute (2017). A Guide to the Project Management Body of Knowledge. 6th ed. Newtown Square, PA: Project Management Institute.

Ramanathan, C. T. \& Narayanan, S. P. (2014). A comparative study among stakeholders on causes of time delay in Malaysian multiple design and build project. IEEE International Conference on Industrial Engineering and Engineering Management, 2015-January, pp. 458-463.

Roscoe, J.T. (1975). Fundamental Research Statistics for the Behavioral Sciences. 2nd ed. New York: Holt, Rinehart and Winston.

Sambasivan, M. \& Soon, Y. W. (2007). Causes and effects of delays in Malaysian construction industry. International Journal of Project Management, 25(5), pp. 517-526.

Sweis, G., Sweis, R., Hammad, A.A \& Shboul, A. (2008). Delays in construction projects: The case of Jordan. International Journal of Project Management, 26(6), pp. 665-674.

Wu, C. H., Hsieh, T. Y. \& Cheng, W. L. (2005). Statistical analysis of causes for design change in highway construction on Taiwan. International Journal of Project Management, 23(7), pp. 554-563.

Yap, J. B. H., Abdul-Rahman, H. \& Chen, W. (2017). Collaborative model: Managing design changes with reusable project experiences through project learning and effective communication. International Journal of Project Management, 35(7), pp. $1253-1271$.

Zidane, Y. J. T. \& Andersen, B. (2018). The top 10 universal delay factors in construction projects. International Journal of Managing Projects in Business, 11(3), pp. 650-672.

\section{AUTHORS' BIOGRAPHY}

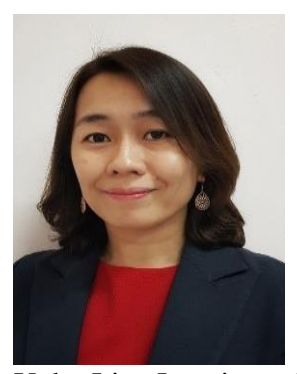

Yoke-Lian Lew is an Assistant Professor in Lee Kong Chian Faculty of Engineering and Science at Universiti Tunku Abdul Rahman, Sungai Long Campus, Malaysia. She received her PhD (Project Management), MSc (Project Management) and BEng (Hons) (Civil) from Universiti Putra Malaysia, and Dip in Civil Engineering from Politeknik Ungku Omar.

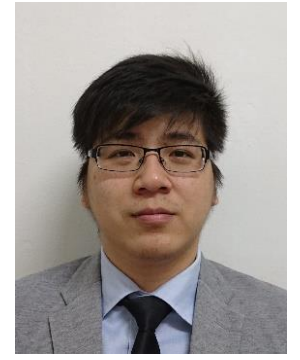

Zan-Xian Ho is a Former Postgraduate Student in Lee Kong Chian Faculty of Engineering and Science at Universiti Tunku Abdul Rahman, Sungai Long Campus, Malaysia. He received his Master (Project Management) from Universiti Tunku Abdul Rahman.

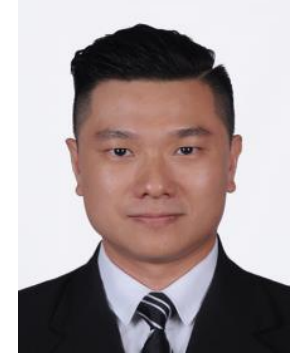

Tien-Choon Toh is an Assistant Professor in Lee Kong Chian Faculty of Engineering and Science at Universiti Tunku Abdul Rahman, Sungai Long Campus, Malaysia. He received his PhD (Quantity Surveying), MSc (Construction Management), BSc (Hons) (Construction), and Dip in Quantity Surveying from Universiti Teknologi Malaysia. 


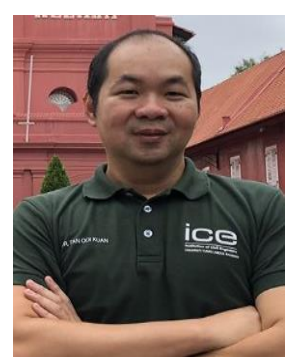

Tan Ooi Kuan is the assistant professor under Lee Kong Chian Faculty of Engineering and Science from the Universiti Tunku Abdul Rahman in Malaysia. He obtained a Doctorate in Business Administration Management in the year 2015 from Universiti Utara Malaysia, His areas of expertise is in Project Management, Marketing and Organizational Behavior.

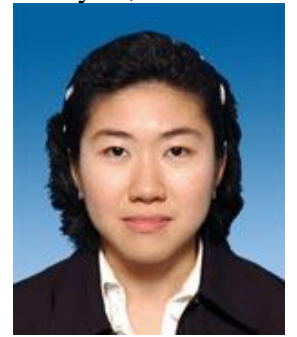

Felicia Yan-Yan Yong is an Assistant Professor and the Head for Department of Surveying in Lee Kong Chian Faculty of Engineering and Science at Universiti Tunku Abdul Rahman, Sungai Long Campus, Malaysia. She received her PhD (Quantity Surveying), MSc (Construction Contract Management), B (Hons) Quantity Surveying from Universiti Teknologi Malaysia.

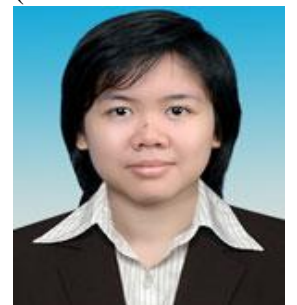

Li Ping Yow is a lecturer in Lee Kong Chian Faculty of Engineering and Science at Universiti Tunku Abdul Rahman, Malaysia. She received her MSc (Construction Contract Management), Bachelor of Quantity Surveying from Universiti Teknologi Malaysia. 